\title{
Ekonomski vidiki pritožb državljanov na ravnanje uradništva: primer uporabe policijskih prisilnih sredstev
}

UDK: $342.7: 351.74$

\author{
Primož Pevcin \\ Fakulteta za upravo, Univerza v Ljubljani \\ primoz.pevcin@fu.uni-lj.si
}

\section{IZVLEČEK}

Reševanje problematike pritožb državljanov na ravnanje uradništva ponavadi temelji na vplivanju na t.i. ponudbene dejavnike pritožb, kot so na primer večji nadzor nad ravnanjem uradništva, dodatno usposabljanje uslužbencev ipd. $V$ praksi ima navedeni pristop pomanjkljivost $v$ demotivacijskih učinkih na aktivnosti uslužbencev, hkrati pa tudi povečuje stroške delovanja uradništva. Tako se je smiselneje in racionalneje reševanja navedene problematike lotiti $z$ vplivanjem na t.i. povpraševalne dejavnike pritožb, s čimer se dejansko skuša vplivati na zmanjšanje možnosti pojavljanja potencialnih primerov ravnanja, ki vodi v pritožbe.

Ključne besede: uradništvo, ravnanje, birokratski output, agencijski problem, pritožbe državljanov

\section{Uvod}

S problematiko pritožb državljanov na ravnanje uradništva in posledičnih možnih odškodninskih zahtevkov se srečuje večina razvitih in demokratičnih držav. ${ }^{1}$ Problematika je postala pereča zato, ker vzpostavitev sodobnega instituta človekovih pravic $v$ povezavi z naraščajočo družbeno-ekonomsko neenakostjo državljanov implicira $v$ skladu $s$ teorijo nasprotij negativen odnos določenih družbenih skupin do državnega aparata. Namreč, sodobna teorija

1 Tudi Slovenija na tem področju ni nobena izjema. Eno izmed področij, kjer je ta problematika še posebej izrazita, je področje delovanja policije. Več o pravnih, ekonomskih in organizacijskih vidikih problematike odškodninske odgovornosti države za ravnanje državnih uslužbencev v Sloveniji glej Seliškar Toš (2005). 
Primož Pevcin

\section{Ekonomski vidiki pritožb državljanov na ravnanje}

birokracije: primer uporabe policijskih prisilnih sredstev

nasprotij, ki se $v$ osnovi naslanja na velika nesorazmerja $v$ porazdelitvi družbene moči, pravi, naj bi družbene skupine, ki imajo v lasti oziroma nadzirajo pomembne družbene vire, uporabljale državni aparat, katerega sestavni del je tudi policija, $v$ določeni meri tudi $z$ namenom prevlade nad dohodkovno šibkejšimi družbenimi skupinami. Skladno s to teorijo naj bi bila policija kot družbeni nadzorni agent države pristojna ne le za omejevanje in preprečevanje kriminala, temveč tudi za nadzor, vodenje in omejevanje družbeno podrejenih skupin (Fielding, 1991), kar pa po drugi strani implicira tudi negativen odnos teh družbenih skupin do državnega aparata.

Osnovni namen prispevka je prikazati institucionalno ekonomske vidike vzrokov pritožb državljanov na ravnanje uradništva, s posebnim poudarkom na analizi ravnanja policistov pri rabi policijskih prisilnih sredstev. Namreč, eden izmed "privilegijev" policije je tudi možnost uporabe prisilnih sredstev, pri čemer se ta tematika $v$ bistvu nanaša na enega izmed vidikov zlorabe policijske moči, to je neustrezne (predvsem prekomerne) rabe prisilnih sredstev, kar zmanjšuje zaupanje javnosti v policijo, negativno vpliva na delovno motivacijo in moralo policistov ter ustvarja konfliktne situacije med državljani in policisti.

Standardni način analize pri proučevanju rabe policijskih prisilnih sredstev ter s tem povezanih potencialnih pritožb državljanov temelji na organizacijskih, socioloških in psiholoških vidikih policijskega dela, kar pomeni proučevanje organizacijske klime, psiholoških značilnosti policistov in njihove nagnjenosti k (prekomerni) uporabi prisilnih sredstev ter družbenih vidikov policijskega dela. ${ }^{2}$ To pomeni, da takšna analiza temelji na proučevanju povezave med starostjo, delovno dobo, nacionalno pripadnostjo policistov ter verjetnostjo in načinom uporabe prisilnih sredstev pri njihovem delu, pa tudi na vidikih nadzora nad njihovim delom. ${ }^{\mathbf{3}}$ Posledično tudi analiza vzrokov za pritožbe na uporabo policijskih prisilnih sredstev temelji na takšnih ugotovitvah. Problem je $\vee$ tem, da pomeni odkrivanje vzrokov na ponudbeni strani nujno povečevanje stroškov policijske organizacije, hkrati pa pretirano iskanje vzrokov pri samih policistih povzroča tudi določene negativne motivacijske učinke.

Obravnavani pristop $\vee$ prispevku je alternativen, saj temelji na t.i. institucionalno ekonomskem vidiku in predstavlja posledično nagradnjo njegovih osnov. ${ }^{4}$ Namreč, v klasični ekonomski terminologiji bi lahko navedeni vidik

2 Več o tem glej Pevcin (2005).

$3 \mathrm{~V}$ veliki večini temelji obstoječa literatura s področja proučevanja policijskega dela ravno na obstoječih treh pristopih.

4 Standardni institucionalno-ekonomski vidik temelji na proučevanju ekonomskih vidikov uveljavljanja zakonodaje in se ukvarja pretežno $z$ ekonomsko analizo različnih podzvrsti prava, kot so naprimer kriminalno pravo, premoženjsko pravo itd. $V$ obravnavanem tekstu je analiza razširjena še na posledice uveljavljanja zakonodaje, to je na rabo prisilnih sredstev in 
proučevanja, ki temelji na organizacijskih, socioloških in psiholoških vidikih, pojmovali tudi kot proučevanje ponudbenih dejavnikov pri uporabi prisilnih sredstev. ${ }^{\mathbf{5}}$ Vendar je to samo eden, čeprav precej standarden, vidik proučevanja. Povsem enakovredno bi namreč lahko pri proučevanju uporabe policijskih prisilnih sredstev proučili tudi drugo plat medalje, to je povpraševalni vidik $^{\mathbf{6}}$, saj lahko tudi prisilna sredstva in njihovo uporabo obravnavamo kot trg, kjer se srečujeta ponudba in povpraševanje. Na strani ponudbe nastopajo policisti, na strani povpraševanja pa kršitelji določenih norm in pravil ravnanja, proti katerim je zato treba uporabiti prisilna sredstva, da se prepreči njihovo nadaljnje nezaželeno ravnanje. Povedano drugače, ti posamezniki so dejansko uporabniki policijskih prisilnih sredstev.

\section{Institucionalno ekonomski vidik uporabe policijskih prisilnih sredstev in problematika pritožb}

Uresničevanje sprejete zakonodaje (z inšpekcijskimi službami, policijo, davčno administracijo, tožilstvom ipd.), z namenom ugotovitve in kaznovanja kršilcev zakonodaje, ima z družbeno-ekonomskega vidika izjemen pomen. ${ }^{7} \mathrm{~V}$ ekonomski literaturi so se prva dela s področja ekonomskih vidikov uresničevanja zakonodaje pojavila že $v$ sredini 18 . stoletja, usmerjena pa so bila na proučevanje ekonomike kaznovanja (več o tem glej de Montesquieu, 1748). Presenetljivo pa je navedeni vidik proučevanja izginil iz ekonomske literature za celi dve stoletji, saj se šele $v 1960$-ih letih ponovno pojavijo ekonomska dela s področja kriminala in sistema kaznovanja kriminalcev (glej Becker, 1968). ${ }^{\mathbf{8}}$

posledično "nezadovoljstvo" oziroma "nestrinjanje" uporabnikov (državljanov) z njihovo uporabo.

5 Ponudbeni vidik je zato, ker se analizira delovanje policijske organizacije in policistov, to je tistih, ki ponujajo prisilna sredstva.

6 Povpraševalni vidik je zato, ker se analizirajo dejavniki na strani uporabnikov prisilnih sredstev, to je tistih, ki se posledično podajajo tudi pritožbe.

$7 \mathrm{Na}$ primer, uresničevanje zakonodaje ima pomemben vpliv na stopnjo onesnaževanja okolja, stopnjo upoštevanja davčne zakonodaje, stopnjo kriminala ipd. Skrb za red in varnosti, kar sodi v sklop policijskega dela, je tudi ena izmed temeljnih funkcij države $v$ skladu $s$ Smithovo filozofijo ekonomskega liberalizma (glej Smith, 1776).

8 Navedeno delo kasnejšega nobelovega nagrajenca za ekonomijo je bilo precej vplivno in je odprlo vrata ekonomistom tudi za proučevanje družbenih pojavov, kateri so bili prej v domeni drugih ved. Dejstvo, da se je proučevanje državnega aparata v ekonomski znanosti pojavilo šele takrat, ne preseneča, saj je vse od prve polovice 19. stoletja do pred nekaj desetletij $v$ prevladujoči ekonomski znanosti prevladovalo prepričanje, da za proučevanje delovanja 
Primož Pevcin

Ekonomski vidiki pritožb državljanov na ravnanje

birokracije: primer uporabe policijskih prisilnih sredstev

$\checkmark$ institucionalnem kontekstu je nadzor dela policistov eden izmed osrednjih problemov policijske organizacije, saj slabo ravnanje policije negativno vpliva na odnos javnosti do nje. Problem uporabe pritožb državljanov zoper policijsko delo kot vira informacij nadzornega mehanizma je $v$ tem, da ima ta metoda svoje prednosti in pomanjkljivosti. Namreč, na navedeno metodo pogosto letijo očitki, da ni objektivna, saj prihaja tako do pojava premajhnega števila pritožb kot tudi do prekomernega števila pritožb. ${ }^{9}$ Po eni strani se državljani bojijo podati uradno pritožbo na ravnanje policistov, medtem ko po drugi strani nekateri državljani podajajo neutemeljene pritožbe, pogosto s ciljem vplivanja na sprejete odločitve sodišč in zavlačevanje ukrepanja proti njim. Pri pritožbah državljanov pa je treba upoštevati še dva vidika, in sicer vidik njihove dejanske neizogibnosti ter vidik kazalca produktivnosti. $\vee$ zvezi s prvim vidikom velja omeniti, da so, glede na naravo policijskega dela, pritožbe zoper njeno delo dejansko neizogibne, saj prihajajo policisti v neposredne konflikte z državljani (Wagner in Decker, 1997), zato se pojavlja vprašanje, kako zanesljiv merilec neustreznega ravnanja policije sploh so.

$\checkmark$ zvezi z drugim vidikom pa velja omeniti, da sicer $\vee$ glavnem pritožbe državljanov zoper delo policije pomagajo identificirati problematične policiste, vendar jih lahko po drugi strani obravnavamo tudi kot neke vrste kazalnike produktivnosti dela policistov. Namreč, $\vee$ praksi je treba preveriti tudi povezavo med pritožbami državljanov in dejanskim obnašanjem policistov, saj so lahko $v$ določeni meri tisti "problematični" policisti, na katerih delo je vloženih veliko pritožb, $\vee$ resnici produktivni policisti. $\vee$ tem kontekstu je treba zaznati pomen pritožb zoper delo policije vsaj $v$ dveh dimenzijah (Terrill in McCluskey, 2002):

- Pritožbe zoper delo policije so slab kazalnik kakovosti dela, saj so nezanesljiv in nepravilen merilec dela policistov. Delež utemeljenih pritožb glede na celotno število pritožb je relativno nizek, kar kaže na to, da je pritožba bolj kot z dejstvom, da je policist naredil napako pri delu, povezana z dejstvom, da posameznika moti že dejstvo vpletenosti v policijski postopek.

državnega aparata praktično ni prostora $v$ ekonomiji. Izjemen metodološki napredek ekonomske teorije $\vee$ zadnjih desetletjih pa je povzročil, da so novejši teoretični pristopi (na primer teorija javne izbire, institucionalna ekonomika ipd.) sposobni rigorozne znanstvene analize državnih institucij na podlagi obstoječe, $v$ veliki meri matematizirane, ekonomske metodologije. $\mathrm{O}$ ekonomskih vidikih policijskega dela in uporabe prisilnih sredstev glej tudi Pevcin (2005).

9 Nekatere ocene kažejo, da naj bi samo tretjina državljanov, ki so bili izpostavljeni neustreznemu ravnanju policije, tudi vložila uradno pritožbo zoper delo policije, pri čemer se pogosto kot vzrok zato pojavlja nizko zaupanje v sam proces vlaganja pritožbe. Po drugih ocenah pa naj bi bil večji problem $v$ tem, da je vloženih precej neupravičenih pritožb, na kar kaže že zelo nizek delež upravičenih pritožb (Lersch in Mieczkowski, 2000). V tem kontekstu je pritožbe na policijsko delo treba jemati le kot barometer uspešnosti policijskega dela oziroma kot koristen vir menedžerskih informacij (Cao in Huang, 2000). 
- $\quad V$ določeni meri naj bi pritožbe državljanov pomagale identificirati problematične policiste, vendar so po drugi strani v določeni meri tudi kazalnik produktivnosti dela policistov. Namreč, verjetno najbolj zanesljiv način, kako se policist izogne pritožbam zoper njegovo delo, je izogibanje kakršnemu koli delu oziroma izogibanje situacijam, ki bi lahko vodile do konfliktov $z$ državljani. ${ }^{10}$

\section{Povpraševalni in ponudbeni vidik pritožb državljanov na uporabo policijskih prisilnih sredstev}

Namen prispevka je prikazati in analizirati vzroke za pritožbe državljanov na rabo prisilnih sredstev kot temelja odškodninskih zahtevkov iz povpraševalnega vidika, saj bi se na takšen način lahko zmanjšale pritožbe kot tudi sami stroški policijske organizacije, ki so povezani z zmanjševanjem števila pritožb. "' Namreč, pritožbe državljanov so nujno povezane tudi s količino uporabljenih prisilnih sredstev. Tako poizkus zmanjševanja pritožb državljanov z vplivanjem na zmanjšanje rabe prisilnih sredstev oziroma njihovo bolj strokovno rabo pomeni dejansko vplivanje na ponudbene dejavnike (npr. večja strokovna in situacijska usposobljenost policistov, večji pregled (interni ali eksterni) nad rabo prisilnih sredstev ipd.), kar pa samo nujno vpliva tudi na povečanje stroškov delovanja policije, ne pozabiti pa velja tudi na negativne zunanje vplive, ki lahko demotivacijsko vplivajo na policiste. $V$ samem bistvu je tako treba za racionalnejšo rabo prisilnih sredstev in $\mathrm{s}$ tem povezano zmanjšanje potencialnih pritožb poiskati rešitve na povpraševalni strani, kar pomeni, da se zmanjša sama potreba po rabi prisilnih sredstev, hkrati pa tudi sama motivacija državljanov za podajanje pritožb. Na podlagi podanih predpostavk lahko izpeljemo prvo premiso in njeno utemeljitev.

10 Argument o produktivnosti policistov je bil delno podprt tudi $v$ študiji avtorjev, ki sta ugotovila, da obstaja pozitivna povezanost med intenzivnostjo izvajanja policijskega dela na področju preverjanja in zasliševanja državljanov ter med pritožbami zoper takšno početje.

11 Navedeni pristop je pionirski in alternativa obstoječemu, njegov cilj pa je prikazati dejanske vzroke za pritožbe državljanov na uporabo prisilnih sredstev, s pomočjo katerih bi lahko pritožbe zmanjšali brez posebnih negativnih stroškovnih in motivacijskih učinkov. 
Primož Pevcin

Ekonomski vidiki pritožb državljanov na ravnanje

birokracije: primer uporabe policijskih prisilnih sredstev

PREMISA 1: Reševanje problematike vzrokov za pritožbe državljanov na rabo policijskih prisilnih sredstev s ponudbenim pristopom, predvsem z večjim eksternim nadzorom upravičenosti in strokovnosti rabe prisilnih sredstev, zaradi agencijskega problema $z$ institucionalnega vidika ni najbolj priporočljivo.

\subsection{Pomanjkljivosti ponudbenega pristopa pri reševanju problematike pritožb državljanov}

Omenili smo že, da se dvom v pravilnost in zakonitost ravnanja uradništva pojavlja praktično na vseh področjih delovanja javnega sektorja, še posebej pogosto na področju uporabe policijskih prisilnih sredstev, pri delovanju davčne administracije ipd. Kljub aktualosti tematike pa je bilo $v$ ekonomski znanosti napravljenih zelo malo študij o vprašanju, kakšen naj bo nadzor delovanja uradništva, še posebej o tem, ali naj bo nadzor interne ali eksterne narave. Čeprav je $\vee$ praksi večina nadzora nad delovanjem policijskih organov interne narave, pa se $v$ zadnjem času glede njenega delovanja pojavljajo tudi številne eksterne institucije, kot so mediji, organizacije za človekove pravice, politične institucije itd.

Zavedati se je treba, da $\vee$ javnem sektorju nastopa agencijski problem zato, ker imamo tri skupine subjektov: družbo (principale), uradništvo (agente) in uporabnike, pri čemer je na splošno naloga agentov dodeljevanje virov uporabnikom. S tem $\vee$ zvezi je eden izmed večjih problemov javnega sektorja ta, da javnost pogosto ne verjame kredibilnosti internih preiskav nepravilnega ravnanja državnih uslužbencev (takšen primer je dvom $v$ iskrenost preiskav ravnanja policistov zaradi prepričanja, da ne bodo "tožarili" drug drugega - t.i. tanka modra linija). Enega izmed razlogov za dvom $v$ kredibilnost je treba iskati $\checkmark$ drugačnih preferencah državnih uslužbencev in prebivalstva, zaradi česar so po eni strani državni uslužbenci lahko bolj učinkoviti, vendar pa šepa njihova sposobnost učinkovitega in kredibilnega nadzora. ${ }^{12}$ Po drugi strani eksterni nadzor nima tega problema, problem pa nastane zaradi slabše informiranosti, saj se ponavadi nadzor izvaja šele takrat, ko se pritoži uporabnik. Za razliko od internega nadzora, katerega primerjalna prednost je $\vee$ tem, da se lahko spremljata tako dodeljevanje virov kot tudi reakcija uporabnikov, pa $\vee$ primeru eksternega nadzora, če se uporabnik ne pritoži, ni mogoče spremljati dodeljevanja virov, temveč na izvajanje nadzora ključno vplivajo uporabniki. Namreč, do

12 Dejstvo je, da je policist, ki težje verjame v nedolžnost osumljenca, verjetno bolj učinkovit $\checkmark$ boju proti kriminalu. 
eksternega nadzora pride šele, ko se pojavijo dokazi o napačnem ravnanju, na katere opozorijo nezadovoljni uporabniki (npr. osumljenec, zoper katerega so bili uporabljena prisilna sredstva na nepravilen način ipd.). $V$ primeru, da uporabniki prevzamejo vlogo ocenjevanja dela, lahko državni uslužbenci enostavno začnejo upoštevati želje uporabnikov tudi v primeru, ko to ni zaželeno, zato da bi se izognili pritožbam. ${ }^{13}$

Nadzor nad uradništvom s preiskavami ravnanja državnih uslužbencev potem, ko principali prejmejo informacije od medijev, interesnih skupin in zakonodajalcev, naj bi zagotavljal, da agenti (uradništvo) ravnajo v skladu z interesi principala (družbe). ${ }^{14}$ Številne ekonomske študije pa opozarjajo na pasti navedenega mehanizma. Na primer, Hopenhayn in Lohmann (1996) sta s tem $\checkmark$ zvezi na primeru regulatornih agencij opozorila na konstantno asimetrijo informacij $\vee$ njihovem nadzoru, katere posledica je prekomeren konzervatizem regulatornih agencij v izdajanju raznih dovoljenj. ${ }^{\mathbf{1 5}}$ Podobno je Prendergastova (2001) pokazala na posledično "nedejavnost" uradništva, ki je posledica negativne stimulacije, ki jo povzročajo pritožbe uporabnikov. Namreč, $v$ že omenjenem agencijskem problemu nastopajo uporabniki in državni uslužbenci na nasprotnih straneh, saj je cilj uporabnika pridobiti neko korist »birokratski output «, medtem ko je naloga uradništva produkcija in razdelitev outputa točno določenim uporabnikom (prejemnikom koristi). $V$ takem primeru vodijo preiskave ravnanja na podlagi pritožb državljanov do tega, da agenti (uaradništvo) v čimvečji meri upoštevajo želje uporabnikov. Namreč, nadzor ravnanja uradništva na podlagi zaznav uporabnikov je izjemno težak, saj so takšne zaznave učinkovitosti in primernosti ravnanja precej nezanesljive. Ključen problem je $\vee$ dejstvu, da uporabniki kot primarni vir informacij o ravnanju uradništva niso kredibilen vir informacij o uspešnosti delovanja uradništva. Razlog je v dejstvu, da precej »birokratskega outputa " predstavlja neko obliko koristi za uporabnike, zato imajo ti popolnoma drugačne preference in niso pripravljeni opozarjati na znane napake. ${ }^{\mathbf{1 6}}$

13 Na primer, policisti se lahko začnejo izogibati kritičnim situacijam in zmanjšajo uporabo prisilnih sredstev.

14 Številne ekonomske analize se ukvarjajo s problematiko uvajanja praks zasebnega sektorja $v$ javni sektor. Problem $v$ javnem sektorju je, da je težko stimulirati zaposlene s plačilom po učinku, saj se državni uslužbenci ponavadi srečujejo z različnimi nalogami, katerih učinke je težko meriti (več o tem glej Dixit, 2002). Ponavadi se stimuliranje v javnem sektorju zagotavlja z nudenjem kariernih možnosti na podlagi zaznavanja usposobljenosti kandidata.

15 Navedena avtorja sta pokazala, da se $v$ primeru izdajanja dovoljenj za prodajo določenih zdravil regulatorni organi zaradi bojazni pred možnimi pritožbami uporabnikov, ki bi jih povzročilo neustrezno zdravilo, zaščitijo tako, da relativno pozno in po dolgotrajnih postopkih izdajo dovoljenje za uporabo in prodajo nekega zdravila.

16 Na primer, težko je pričakovati, da bo prestopnik, ki se je izognil aretaciji, zatožil policista, ker ga le-ta ni aretiral. 
Primož Pevcin

\section{Ekonomski vidiki pritožb državljanov na ravnanje}

birokracije: primer uporabe policijskih prisilnih sredstev

Osnovna dilema pri nadzoru nad uradništvom je $\vee$ tem, ali naj uradniška dela opravljajo posamezniki, ki so bolj ali manj dovzetni za zahteve uporabnikov kot družba. Prendergastova (2001) pravi, da naj bi uradniška dela opravljali posamezniki, ki so manj dovzetni za zahteve uporabnikov, ker jim to po drugi strani omogoča sprejemati boljše odločitve. Namreč, naloga državnih uslužbencev je pravilna alokacija resursov uporabnikom, na primeru policije je to skrb za preprečevanje kriminala. $\vee$ tem kontekstu je osnovna dilema, kakšne policiste zaposliti: ali tiste, ki jih bolj skrbi, da bo nedolžna oseba obsojena ali tiste, ki jih bolj skrbi dejstvo, da bi bil krivec lahko izpuščen. Med navedenima primeroma je namreč bistvena razlika, saj $\vee$ prvem primeru obstajajo številni mehanizmi, ki preprečujejo nezaželene izide: pritožbe osumljencev, sojenje ipd., ki zmanjšujejo verjetnost, da bi bila nedolžna oseba obsojena. Po drugi strani pa je majhna verjetnost, da bo odkrita napaka policista, ki izpusti krivega osumljenca, saj osumljenec nima interesa, da bi razkril napako policista. To pomeni, da je s tega vidika veliko bolj koristen policist, ki ga bolj skrbi možnost, da bi bil krivec izpuščen.

$S$ tem $\vee$ zvezi pa je pogled popolnoma drugačen glede nadzora. Namreč, prednost internega nadzora je boljše poznavanje postopkov in predvsem primerov rutinskega ravnanja, kar nadzornikom omogoča, da nagrajujejo posamezne državne uslužbence tudi v primeru sprejemanja težkih odločitev. Po drugi strani pa je problem internega nadzora $\vee$ tem, da je pogojen $\vee$ precejšnji meri $s$ preferencami posameznikov in njihovo voljo po opozarjanju na napake (t.i. uradniška pristranskost). Problem postane še večji, saj so državni uslužbenci v povprečju manj dovzetni za zahteve uporabnikov, kar pomeni tudi nizko odzivnost na legitimne zahteve uporabnikov. Povedano drugače, tisto kar dela državne uslužbence bolj učinkovite jih po drugi strani dela slabše nadzornike. Vendar ima tudi eksterni nadzor svoje prednosti in pomanjkljivosti. Namreč, eksterni nadzor nima problema pristranskosti, vendar pa nastopi problem slabše informiranosti, saj do nadzora pride ponavadi šele ob pojavu "pretiranega" nezadovoljstva uporabnikov. ${ }^{\mathbf{1 7}}$ Tako niso eksterni nadzorniki usmerjeni na vse primere napak državnih uslužbencev, ampak samo na tiste, kjer je bil oškodovan uporabnik. To lahko povzroči, da so državni uslužbenci motivirani za izogibanje nadzora, tako da upoštevajo zahteve uporabnikov.

Problematika nadzora uradništva izvira iz dejstva, da proizvaja predvsem dobrine in storitve, katerih uporabe ni mogoče neposredno zaračunati. Namreč, če bi bilo uporabo dobrine mogoče zaračunati, bi prišlo do pritožb uporabnikov $\checkmark$ dveh primerih: (a) če bi uporabnik dobil dobrino, ki je ne potrebuje, in (b) če bi uporabnik ne dobil dobrine, ki jo potrebuje. $V$ primeru večine dobrin, ki 

birokracije: primer uporabe policijskih prisilnih sredstev

jih proizvaja uradništvo, to je javnih dobrin, pa se pritožijo samo uporabniki, ki ne dobijo dobrine. Navedena karakteristika javnih dobrin, to je neposredno neplačevanje za njihovo uporabo, dejansko pripelje do agencijskega problema pri eksternem uradniškem nadzoru. Tako ima interni nadzor sicer prednost $v$ tem, da imajo interni nadzorniki možnost trajno nadzorovati ravnanje uradništva ( $v$ vseh njenih aktivnosti), slabost pa je $\vee$ tem, da $v$ uradništvu praktično ni vzvodov za nagrajevanje $v$ primeru dobrega ravnanja - edini način motiviranja državnih uslužbencev je pogosto povezan le z grožnjami z odpustom, ponavadi $\vee$ primerih večjih kršitev in nedopustnih oblik ravnanja, obstaja pa malo mehanizmov pozitivne motivacije. Zaradi takšne situacije je problem "poštenosti« (pozitivnega pristopa) agentov še posebno velik, saj jih nadzorniki kljub dobremu delu, preprosto ne morejo nagraditi. Ker je naloge in rezultate dela državnih uslužbencev težko določati, meriti in nadzirati, tudi ni vzvodov plačevanja po uspešnosti, kar je značilno za zasebni sektor. $\vee$ takem primeru so edino uporabniki tisti, ki lahko opozorijo na napake, zastonjkarstvo pa dela uporabnike precej nezanesljive subjekte za ugotavljanje napak.

Policija je tipičen primer uradniškega področja s konstantno asimetrijo $v$ odzivih uporabnikov na njeno ravnanje. Osnovni nalogi policije sta skrb za javno varnost in boj proti kriminalu. Asimetrija $v$ odzivih uporabnikov se kaže $v$ dejstvu, da se na policijsko ravnanje pritožujejo le posamezniki, proti katerih so bila na primer po nepotrebnem (ali pa neustrezno) uporabljena prisilna sredstva, ne pritožujejo pa se posamezniki, ki so se izognili policijski obravnavi, čeprav bi si jo zaslužili. ${ }^{18}$ To dejstvo povzroča, da so pritožbe uporabnikov dejansko samo enostranske. Rezultat zanašanja na takšne pritožbe pri nadziranju policijskega dela pogosto vodi v situacije, da se policisti enostavno začnejo izogibati situacijam, ki bi lahko vodile do pritožb uporabnikov. Razlog je v preprostem dejstvu: previdnejše in korektnejše delo pri uporabi prisilnih sredstev sicer lahko zmanjša število pritožb zoper policista, vendar to povzroča dodatne stroške policistu (izobraževanje, študija situacij ipd.), nenazadnje pa tudi državi. Precej lažje je doseči zmanjšanje števila pritožb z zmanjšanjem aktivnosti, torej z manj agresivnim pristopom do boja proti kriminalu.

17 Pozornost nadzornikov ponavadi pritegne nepravilno ravnanje policije ob aretaciji in ne ravnanje policije ob izpustitvi sicer krivega osumljenca.

18 Sicer obstajajo pritožbe državljanov na nerešene prestopke ali opuščanje aretacij zločincev, vendar je takšne pritožbe praktično nemogoče naprtiti točno določenemu policistu. 
Primož Pevcin

Ekonomski vidiki pritožb državljanov na ravnanje

birokracije: primer uporabe policijskih prisilnih sredstev

\subsection{Ponudbeni pristop in izkušnje v praksi}

Povečana odzivnost policijske organizacije na večje število pritožb državljanov (na primer $v$ obliki povečanega eksternega nadzora nad delovanjem), ki posledično lahko pripelje do zmanjšane aktivnosti policijskega dela, ima tudi negativne stranske učinke, še posebej, če se "uporabniki" začnejo zavedati tega. Navedene trditve dokazujejo tudi analize Prendergastove (2001) in Shija (2005) za policijski organizaciji v Los Angelesu in Cincinnatiju. Uvedba intenzivnega eksternega nadzora policijskega dela, ki je bil posledica medijske pozornosti ob nemirih ${ }^{\mathbf{1 9}}$ (leta 1998 v Los Angelesu in leta 2001 v Cincinnatiju), je dejansko pomenila asimetrično pozornost do policijskega dela, kar je ob izostanku sprememb sistema sankcioniranja policistov, ki jim ni uspelo kaznovati prestopnikov, vodilo do zmanjšane aktivnosti dela policistov in njihove agresivnosti v boju proti kriminalu.

Namreč, Prendergastova (2001) je pokazala, da je povečan eksterni nadzora nad delovanjem policije po nemirih v Los Angelesu leta 1998 vodil do zmanjšane aktivnosti policije oziroma njene večje pasivnosti, saj se je v letih 1999 in 2000 zmanjšalo število aretacij glede na število storjenih kriminalnih dejanj, kar je bilo še posebej izrazito na tistih področjih delovanja policije, kjer imajo policisti pri svojih aktivnosti največ diskrecijskih pravic ${ }^{20}$ in kjer je agencijski problem še posebej izrazit ${ }^{\mathbf{2 1}}$, zmanjšalo pa se je tudi število napadov na policiste, kar dokazuje tezo o izogibanju konfliktnim situacijam. Do podobnih ugotovitev je prišel tudi Shi (2005) s proučevanjem policijske organizacije v Cincinnatiju po nemirih v letu 2001, ko se je število aretacij na področju boja proti mamilom in prestopkov povezanih z zlorabami alkoholnih substanc zaradi povečanega eksternega nadzora nad delovanjem policije zmanjšalo kar za $46 \%$ oziroma $74 \%$, izrazit pa je bil tudi upadec števila izrečenih kazni na področju prometne varnosti, in sicer kar za dobro polovico. ${ }^{\mathbf{2 2}}$ Shi je podobno kot Prendergastova tudi ugotovil, da se je

19 Nemiri, nekakšna ekstremna oblika pritožb uporabnikov, so bili posledica burnega odziva določenih socialnih skupin na domnevno nekorektno in pretirano rabo prisilnih sredstev s strani policije.

20 Takšne aktivnosti so na primer boj proti prometu z mamili in alkoholom, prometna varnost ipd., pri katerih je kršitev zakonodaje $v$ največji meri znana šele ob kontaktu z osumljencem.

21 Analize so pokazale, da se je najbolj zmanjšalo število aretacij na področju boja proti proizvodnji in preprodaji mamil, ki velja za eno izmed področij, kjer se osumljenci dejansko pogosto ne zavedajo aktivnosti policije vse do takrat, ko so aretirani. Podatki Prendergastove so pokazali, da se je v Los Angelesu število aretacij na tem področju v obdobju 1998-2000 zmanjšalo kar za $40 \%$, kar potrjuje domneve o precejšnji odzivnosti policistov na povečan eksterni nadzor ter o posledičnih vedenjskih spremembah.

22 V skupnem se je število aretacij zmanjšalo za dobrih $25 \%$. Pri tem ne gre zanemariti dejstva, da se je $v$ proučevanem obdobju stopnja kriminala $\vee$ Cincinnatiju celo povečala (za 16\%). Še posebej je bil izrazit porast kriminala na tistih področjih, ki so bolj "občutljiva" na policijsko delo, kar pomeni, da je njihovo odkritje bolj povezano z samimi aktivnostmi policije. Tako se je na 
najbolj opazno zmanjšala aktivnost policistov na tistih področjih dela, kjer je sama uspešnost dela odvisna predvsem od "agresivnosti" delovanja. ${ }^{\mathbf{2 3}}$ Vse to dokazuje, da povečan nadzor nad policijskim delovanjem ne vodi do večje obzirnosti policistov pri njihovem ravnanju, temveč enostavno do zmanjšane aktivnosti, kar je posledično vodilo tudi do porasta kriminalitete. ${ }^{\mathbf{2 4}}$

Izkušnje v praksi tako očitno kažejo, da povečan eksterni nadzor nad policijskim delom ne pripelje do bolj "mehkega" pristopa pri rabi prisilnih sredstev, temveč do zmanjšane aktivnosti policistov - dejansko pride do disfunkcionalnega odziva policije. Navedena ugotovitev pa ni značilna samo za policijsko organizacijo, temveč lahko pride do disfunkcionalnega odziva pri vseh tistih aktivnostih uradništva, kjer uporabniki lahko pridobijo neko korist (bodisi v pozitivnem ali negativnem smislu) od alokacije resursov uradništva, čeprav si te alokacije ne zaslužijo. Natančneje, z vidika nadzora so problematične tiste aktivnosti, kjer (a) uporabniki pridobijo neko korist od birokratskih resursov in (b) kjer so povratne informacije osnova za ocenjevanje uspešnosti dela državnih uslužbencev. ${ }^{\mathbf{2 5}}$ Glede na to, da imajo pritožbe uporabnikov lahko zelo pomemben učinek na karierne možnosti državnih uslužbencev, se lahko le-ti odločijo, da bodo $v$ večji meri upoštevali zahteve uporabnikov. Negativni učinek eksternega nadzora je zaradi tega ravno $v$ tem, da lahko precej zmanjša motivacijo državnih uslužbencev za opravljanje dela. ${ }^{\mathbf{2 6}}$ Glede na navedeno se je smiselno lotiti reševanja problematike pritožb državljanov na uporabo policijskih sredstev iz povpraševalnega vidika, kar lahko strnemo v spodnji premisi.

PREMISA 2: Pri reševanju problematike pritožb državljanov na rabo policijskih prisilnih sredstev se je iz institucionalnega vidika smiselneje bolj osredotočiti na t.i. povpraševalne dejavnike pritožb. Izpostavimo lahko vsaj tri dejavnike: (a) negativne spodbude $z$ uporabo groženj z nasiljem, (b) pričakovane koristi od pritožbe za uporabnika in odzivnost nadzornikov na pritožbe in (c) stopnjo kriminala.

primer število ropov in kraj avtomobilov $v$ navedenem obdobju $v$ Cincinnatiju povečalo kar za $45 \%$ oziroma za $68 \%$.

$23 \mathrm{Na}$ primer, na področju nasilja $v$ družini se aktivnost policijskega dela ni bistveno zmanjšala, deloma tudi zato, ker gre za prekršek, ki je največkrat znan šele, ko žrtev pokliče policijo, ki se mora odzvati.

24 Izračuni Shija so pokazali, da sta elastičnosti nasilniškega in premoženjskega kriminala glede na aktivnosti policije približno -1.3 in -0.5 .

25 Takšen primer dejavnosti je tudi izobraževanje.

26 Na primer, policisti enostavno zmanjšajo svoje aktivnosti v boju proti kriminalu. 
Primož Pevcin

Ekonomski vidiki pritožb državljanov na ravnanje

birokracije: primer uporabe policijskih prisilnih sredstev

\subsection{Alternativni (povpraševalni) vidik reševanja problematike pritožb državljanov na uporabo policijskih prisilnih sredstev}

Najučinkovitejši način za zmanjšanje pritožb državljanov na uporabo policijskih prisilnih sredstev je seveda $\vee$ zmanjšani rabi prisilnih sredstev, pri čemer se lahko raba prisilnih sredstev zmanjša z "obzirnejšim" ravnanjem policije (t.i. ponudbeni vidik) ali pa z zmanjšano potrebo po rabi prisilnih sredstev (t.i. povpraševalni vidik). $\vee$ praksi se ponavadi reševanja navedene problematike $\vee$ policijskih organizacijah lotijo s prvim pristopom, to je z vplivanjem na t.i. ponudbene dejavnike, kot so na primer dodaten nadzor nad rabo prisilnih sredstev, usposabljanje policistov ipd. Problematika navedenega pristopa je, da implicitno povečuje stroške delovanja, poleg tega pa predvsem instrument nadzora lahko povzroča nezaželene negativne motivacijske učinke $\vee$ obliki zmanjšanega delovnega napora pri policistih, ki tudi na takšen poskušajo zmanjšati stroške opravljanja svojega poklica. Namesto tega se zdi bolj smotrno vplivati na t.i. povpraševalne dejavnike. Kar se tiče povpraševalnih dejavnikov rabe prisilnih sredstev, lahko izpostavimo nekaj le-teh ${ }^{\mathbf{2 7}}$ :

- Negativne spodbude državljanom v obliki groženj z uporabo prisilnih sredstev kot obliko nasilja, ki učinkovito zmanjšujejo potrebo po rabi prisilnih sredstev. $\vee$ tej zvezi je ena izmed implikacij uporabe prisilnih sredstev tudi ta, da je uporabo prisilnih sredstev mogoče zmanjšati tudi s povečanjem groženj z uporabo nasilja. Dejstvo je, da je z metodo nasilja težko kaj doseči, saj predstavlja nasilje neki osebi dejansko le t.i. potopljene stroške in zato ne vpliva na njeno nadaljnje vedenje. Tisto, kar vpliva na ravnanje nekega posameznika, je grožnja z nadaljnjim nasiljem, že prejeto nasilje pa služi zgolj kot informacija o možnosti in moči. ${ }^{28}$ Običajen način, kako spraviti osebo $v$ zapor, je tako grožnja z nasiljem (npr. z uporabo gumijevke, prijema itd.), pri čemer pogosto do dejanske uporabe nasilja niti ne pride. Namreč, za policijski aparat, ki je pripravljen uporabiti nasilje, je značilno, da mu ga

27 Bralca opozarjamo, da gre $v$ veliki meri za pionirski pristop pri analizi navedenega področja, zato vsa vprašanja in problematika nikakor niso $v$ celoti obdelana, saj je potrebna še nadaljnja diskusija.

28 Na primer, razlog, zakaj prestopnik sledi policistu $v$ zapor, ni $v$ tem, da ga je le-ta udaril oziroma uporabil prisilna sredstva, temveč v bojazni, da bo tepen. Poleg tega je osebo težko spraviti $\vee$ zapor ne da bi grozili z uporabo nasilja. Namreč, če želimo posameznika fizično omejiti in zapreti brez poškodb, bomo za eno osebo najverjetneje potrebovali tri do štiri policiste, hkrati pa je skoraj gotovo, da bodo policisti med tem dejanjem tudi sami utrpeli kakšno poškodbo $v$ primeru močnejšega upiranja aretiranega. To pa s seboj prinaša dodatne stroške, saj bi bilo treba policistom zagotoviti dovolj visoko plačo, ki bo odtehtala verjetnost fizične poškodbe, poleg tega pa bi to vplivalo tudi na potrebno povečanje policijskega aparata, ki bi bil potreben za ročno prenašanje aretiranih, $v$ kar pa bi težko prepričali večino davkoplačevalcev. 

birokracije: primer uporabe policijskih prisilnih sredstev

je le redko treba uporabiti, saj že sama grožnja z uporabo nasilja in demonstracija moči delujeta dovolj prepričljivo, hkrati pa je to iz družbenega vidika povzroča tudi nižje stroške. Tiha grožnja z uporabo nasilja je tako dejansko potrebna, kar pa utemeljuje tudi potrebo po obstoju policijskega aparata, saj se $s$ tako obliko kolektivne akcije $v$ družbi odpravlja problem pripornikove dileme, s čimer se povečuje tudi neto izid družbe (Tullock, 1974).

- Pričakovana korist od podane pritožbe za državljana (tudi v obliki nanesene karierno-materialne škode policistu) ter odzivnost policijske organizacije in nadzornikov na pritožbe državljanov. Pričakovati je, da bo večja odzivnost policije (in drugih institucij) na pritožbe državljanov na rabo policijskih prisilnih sredstev, kar bi $v$ praksi lahko izhajalo tudi iz možnosti lažjega (na primer elektronskega) načina podajanja pritožb, sama po sebi vodila do večjega števila pritožb. ${ }^{\mathbf{2 9}}$ Poleg tega večja odzivnost na pritožbe lahko vpliva tudi na ravnanje policistov, saj se le-ti zavedajo negativnega kariernega učinka pritožb ${ }^{\mathbf{3 0}}$, zato postanejo bolj previdni pri svojem delu, spremenijo pa lahko tudi samo ravnanje in njegovo intenzivnost, katerega cilj je zmanjšanje možnosti dobiti pritožbo na svoje ravnanje. Obnašanje policistov se lahko spremeni v več smereh, saj lahko policisti postanejo bolj previdni in konzervativni pri rabi prisilnih sredstev, lahko se začnejo izogibati situacijam, $v$ katerih bi lahko prišlo do potrebe po rabi prisilnih sredstev, nenazadnje pa lahko enostavno zmanjšajo intenzivnost dela.

- Stopnja kriminala. Povsem jasno je, da večja stopnja (odkritega) kriminala pozitivno vpliva na potrebo po rabi prisilnih sredstev, kar pomeni, da je treba zmanjšati tudi stopnjo kriminala. Ekonomski vidik navedene problematike se nanaša predvsem na sistem sankcij proti prestopnikom. ${ }^{\mathbf{3 1}} \mathrm{V}$ tem kontekstu je treba proučiti dejavnike, ki vplivajo na odločanje za storitev kriminalnega dejanja, kar z drugimi besedami pomeni, da je treba določiti dejavnike, ki določajo ponudbo kriminalnih dejanj. Tako je Smith (1776) zaključil, da do kriminala pride $v$ vsaki družbi, $\vee$ kateri obstajajo premoženjsko-dohodkovne razlike med ljudmi. ${ }^{32}$ Pri tem pa velja tudi dejstvo, da se tudi kriminalci odločajo

29 Razlog je najbrž iskati tudi $v$ dejstvu, da ima tudi podajanje pritožb svojo ceno - večja odzivnost policije implicitno znižuje ceno pritožbe, kar posledično vodi do večjega števila podanih pritožb.

30 Večje število prejetih pritožb ponavadi pomeni tudi večjo možnost za poklicne sankcije proti policistu.

31 Osnovna dilema pri zmanjševanju stopnje kriminala je, ali naj se $s$ tem namenom povečajo kazni za storilce kriminalnih dejanj. Problem pri navedeni relaciji je, da bi uniformno povečanje kazni za vse vrste kriminalnih dejanj vodilo implicitno do relativno večjega števila tistih "večjih" zločinov, razlog pa leži v marginalnosti odločanja kriminalcev.

$32 \mathrm{~V}$ praksi to dejansko pomeni, da večja premoženjsko-dohodkovna neenakost $v$ družbi implicira tudi večjo stopnjo kriminala, saj ljudi v takem primeru žene želja po pridobitvi premoženja drugih. Tukaj je iskati enega izmed možnih razlogov za porast kriminalitete $v$ t.i. tranzicijskih državah. 
Primož Pevcin

Ekonomski vidiki pritožb državljanov na ravnanje

birokracije: primer uporabe policijskih prisilnih sredstev

racionalno in pred svojim dejanjem pregledajo anticipirane stroške in koristi svojega početja, pri čemer med stroške sodijo možnost ujetja, obsodbe in zapora, koristi pa predstavlja izplen kriminalnega dejanja. Takšna analiza ponudbe kriminala nam omogoča ugotoviti načine, kako zmanjšati kriminal z zmanjšanjem neto pričakovanih koristi storilcev kriminalnih dejanj, pri čemer je treba izpostavitvi pomen povečanja verjetnosti odkritja in izsleditve storilca kriminalnega dejanja ter pomen sankcij pri zmanjševanju kriminala. Številne študije navedenih dveh področij so podale precej nejasne ugotovitve. $V$ pregledu študij so Miller in drugi (2003) izpostavili, da naj bi imela stopnja odkritja in izsleditve kriminalcev zelo majhen vpliv na stopnjo kriminala, medtem ko naj bi večina analiz učinka policije in sistema sankcij na stopnjo kriminala pokazala, da večja policijska aktivnost celo povečuje stopnjo kriminala. Sicer so te trditve potrjene tudi z empiričnimi analizami, vendar so avtorji pogostokrat pozabili na metodološke pasti. Namreč, v praksi se pogosto pojavlja primer, ko se ljudje, ki živijo na področjih z visoko stopnjo kriminala, dejansko želijo zavarovati pred tem pojavom s tem, da želijo imeti večjo prisotnost policije, pa tudi kriminalce želijo bolj kaznovati. ${ }^{\mathbf{3}}$ Ameriški ekonomist Levitt je $v$ seriji člankov $s$ področja ekonomike kriminala analiziral dejavnike, ki vplivajo na stopnjo kriminala, ter prikazal dejanske koristi in omejevalne učinke policijskega dela na kriminaliteto. Tako je na podlagi proučevanja kriminala $\vee$ večjih ameriških mestih v obdobju 1970-1992 ugotovil, da večja prisotnost policije na terenu dejansko vpliva negativno na stopnjo kriminala (Levitt, 1998). ${ }^{\mathbf{3 4}} \mathrm{V}$ istem kontekstu je Levitt (1998a) izpostavil tudi vlogo kaznovanja kot (de)motivacijskega elementa pri kriminalnih dejanjih in ugotovil, da strogost sistema kaznovanja $\vee$ povprečju izrazito negativno vpliva na stopnjo kriminala. ${ }^{35}$

33 Gledano $z$ ekonometričnega vidika je $v$ takem primeru treba upoštevati kavzalnost in/ali endogenost proučevanih spremeljivk. Brez tega lahko nudijo rezultati analiz popolnoma napačne interpretacije.

34 Levitt (2002) je izračunal, da naj bi bila elastičnost t.i. nasilniškega kriminala glede na policijsko aktivnost -1.0, t.i. premoženjskega kriminala pa -0.3, kar drugače povedano pomeni, da naj bi $10 \%$ povečanje števila policistov na terenu zmanjšalo nasilniški kriminal za $10 \%$, premoženjskega pa za 3 \%. Poleg tega je Levitt (2002) tudi izpostavil stroškovne vidike delovanja policije in ugotovil, da pomeni strošek zaposlitve dodatnega policista na terenu le približno $40 \%$ prihrankov, ki jih družba pridobi zaradi posledične manjše kriminalitete.

35 Levitt je pri analizi vzrokov porasta mladoletniškega kriminala $v$ zadnjih desetletjih ugotovil, da na stopnjo kriminala odločilno vpliva ravno sistem kaznovanja, saj je pokazal, da strog režim kaznovanja mladoletnih prestopnikov in nekoliko blažji režim kaznovanja "odraslih" prestopnikov vodi do povečane kriminalitete mladoletnikov, ko le-ti dopolnijo 18 let. 

birokracije: primer uporabe policijskih prisilnih sredstev

\section{Sklep}

$\checkmark$ praksi se države lotevajo reševanja problematike pritožb državljanov na ravnanje uradništva kot temelja svoje odškodninske odgovornosti s poskusom vplivanja na t.i. ponudbene dejavnike pritožb, kot so na primer večji nadzor nad ravnanjem uradništva, dodatno usposabljanje državnih uslužbencev ipd., pri čemer ima navedeni pristop številne pomanjkljivosti, glavni dve se kažeta $v$ demotivacijskih učinkih na državne uslužbence in v povečanju stroškov delovanja uradništva. $\vee$ prispevku so tako prikazane značilnosti alternativnega pristopa $k$ reševanju navedene problematike na področju rabe policijskih prisilnih sredstev, ki pomeni vplivanje na t.i. povpraševalne dejavnike pritožb državljanov. Med navedenimi dejavniki lahko izpostavimo povečanje groženj policije z uporabo nasilja in demonstracijo moči ter zmanjšanje kriminalitete, kar dejansko zmanjšuje potrebo po rabi prisilnih sredstev in s možnost pritožb državljanov. Poleg tega lahko kot enega izmed povpraševalnih dejavnikov izpostavimo tudi zmanjšanje pričakovanih potencialnih koristi za državljane od podajanja pritožb ter manjšo odzivnost nadzornikov na pritožbe, saj navedeni dejavnik $s$ svojim negativnim demonstracijskim učinkom na potencialne pritožnike dejansko vpliva na zmanjšanje števila pritožb.

Dr. Primož Pevcin je doktor ekonomskih znanosti. V svojem raziskovalnem delu se ukvarja pretežno s proučevanjem ekonomskih vidikov politike in prava, v pedagoškem delu na Fakulteti za upravo pa sodeluje pri izvedbi predmetov Temelji ekonomije in Ekonomika javnega sektorja. 
Primož Pevcin

Ekonomski vidiki pritožb državljanov na ravnanje

birokracije: primer uporabe policijskih prisilnih sredstev

\section{Literatura}

- Becker, G.S. (1968): Crime and Punishment: An Economic Approach, Joournal of Political Economy, 76, 2, str. 169-217.

- Cao, L. in Huang, B. (2000): Determinants of citizen complaints against police abuse of power, Journal of Criminal Justice, 28, 3, str. 203-213.

- De Montesquieu, C. (1748/1989): The Spirit of the Laws, Cambridge University Press, Cambridge.

- Dixit, A. (2002): Incentives and Organizations in the Public Sector: An Interpretative Review, Journal of Human Resources, 37, str. 696-727.

- Fielding, N.G. (1991): The Police and Social Conflict, Althone Press, London.

- Hopenhayn, H., Lohmann, S. (1996): Fire-alarm Signals and the Political Oversight of Regulatory Agencies, Journal of Law, Economics, and Organization, 12, str. 196-213.

- $\quad$ Lersch, K.M. in Mieczkowski, T. (2000): An examination of convergence and divergence of internal and external allegations of misconduct filed against police officers, Policing: An International Journal of Police Strategies \& Management, 23, 1, str. 5468.

- Levitt, S.D. (1998): Why Do Increased Arrest Rates appear to Reduce Crime: Detterence, Incapacitation, or Measurement Error?, Economic Inquiry, 36, 3, str. 353-372.

- Levitt, S.D. (1998a): Juvenile Crime and Punishment, Journal of Political Economy, 106, 6, str. 1156-1185.

- Levitt, S.D. (2002): Using Electoral Cycles in Police Hiring to estimate the effects of Police on Crime: Reply, American Economic Review, 92, 4, str. 1244-1250.

- Miller, R.L. et.al. (2003): The Economics of Public Issues, Addison Wesley, Boston.

- Pevcin, P. (2005): Institucionalni vidik pritožb državljanov na uporabo policijskih prisilnih sredstev: teorija in praksa v razvitih državah. V: Seliškar Toš, M. (ur.): Odgovornost države, lokalnih skupnosti in drugih nosilcev javnih pooblastil za ravnanje svojih organov in uslužbencev, Zbornik Inštituta za primerjalno pravo, IPP, Ljubljana, str. 87-97.

- Prendergast, C. (2001): Selection and Oversight in the Public Sector, with the Los Angeles Police Department as an example, Working Paper No. 8664, National Bureau of Economic Research, Cambridge.

- Seliškar Toš, M., ur. (2005): Odgovornost države, lokalnih skupnosti in drugih nosilcev javnih pooblastil za ravnanje svojih organov in uslužbencev, Inštitut za primerjalno pravo, Ljubljana.

- Shi, L. (2005): Does Oversight Reduce Policing? Evidence from the Cincinnati Police Department After the April 2001 Riot, SSRN Working Paper. 

birokracije: primer uporabe policijskih prisilnih sredstev

- Smith, A. (1776/1976): An Inquiry into the Nature and Causes of the Wealth of Nations, University of Chicago Press, Chicago.

- Terrill, W. in McCluskey, J. (2002): Citizen complaints and problem officers, Journal of Criminal Justice, 30, 2, str. 143-155.

- Tullock, G. (1974): Social Dilemma: The Economics of War and Revolution, Center for Study of Public Choice, Blacksburg.

- Wagner, A.E. in Decker, S.H. (1997): Evaluating citizen complaints against the police. V: Dunham, R.G. in Alpert, G.P.: Critical issues in policing, 3. izdaja, Waveland Press, Prospect Heights, str. 275-291. 
Primož Pevcin

Ekonomski vidiki pritožb državljanov na ravnanje

birokracije: primer uporabe policijskih prisilnih sredstev

\section{SUMMARY}

\section{Economic aspects of the issue of citizen complaints against bureaucratic activities}

There has been a tendency of increased number of citizen complaints against bureaucratic activities in the majority of developed and democratic countries. The main reasons for this tendency are predominantly rising socio-economic inequality in modern societies and the emphasised issue of human rights, which contributes to larger awareness of people when seeking for their rights. In this context, the contemporary conflict theory stresses that bureaucracy is nowadays often seen as an instrument of politically and economically privileged classes through which they exercise social control over marginalised groups of population. Consequently, it is to be expected that this would imply strained relations between bureaucracy and those marginalised social groups. This can be also observed in increased number of citizen complaints against bureaucratic activities, in particular those that are impartially seen as unfunded, and are filled primarily to gain some benefit or to avoid responsibility. Besides, strained relations could also affect the confidence in bureaucratic impartiality, thereby causing that citizens see complaints as useless and are averted to fill them.

Consequently, these two problems (so-called over- and underreporting) cause that citizen complaints can be a very poor indicator of the quality of bureaucratic work and ouput for their biasness. Moreover, focusing on citizen complaints as a tool of bureaucratic quality monitoring can be very problematic, since they can be used for measuring bureaucratic productivity and work effort. Namely, if bureaucrats perceive that they are monitored primarily through citizen complaints against their activities, they can be compelled to avoid those complaints by simply reducing their work effort or becoming more prudent as the simplest ways to avoid making mistakes and subsequent complaints. The reduced work effort and growing cautiousness have been found in practice in many bureaucratic activities, in particular in regulatory agencies and police organisations.

In this context, the issue of citizen complaints against the (excessive) use of police force has been preoccupying many practitioners and 
scholars in the majority of developed and democratic countries. Namely, this problem has escalated in magnitude in recent years, as the number of citizen complaints against police activities has been growing, yet the success in solving this problem has been very limited. The majority of theoretical as well as practical studies have focused on organisational, sociological or psychological determinants of citizen complaints and excessive use of police force. From the perspective of the paper, those studies focused mainly on the so-called supply-side factors of this issue, meaning that this approach has its own limits as it necessarily puts additional burdens on police organisations in the form of larger operating costs and disincentive effects on working efforts of police officers. Consequently, the alternative, (so-called demand-side) approach in finding solution to the problem of citizen complaints is discussed in the paper. This alternative approach focuses on the demand-side factors of citizen complaints against police use of force, the real advantage of this approach being in (directly or indirectly) reduced costs of police use of force. The possible demand-side factors analysed in the paper are the increased demonstration of police force and reduced crime rate, which, in essence, reduce the necessity for police to use force. Besides, the issues of increased responsiveness of monitoring agencies toward citizen complaints and the reduced implicit price of filling complaints by citizens are discussed, since they increase the number of complaints against police activities. 